\title{
ENHANCING DESCRIPTIVE WRITING ACHIEVEMENT OF TENTH GRADERS BY USING INTERNET MEME PICTURE
}

\author{
Rita Inderawati, Dea Nova Ariani, Muslih Hambali \\ Sriwijaya University, Indonesia \\ (deanovaariani22@gmail.com,)
}

Received: $08^{\text {th }}$ September 2018; Revised: $15^{\text {th }}$ November 2018; Accepted: $28^{\text {th }}$ Desember 2018

\begin{abstract}
The objectives of this study were to find out whether or not: (1) there was a significant difference in Descriptive Writing achievement after the tenth grade students of SMA Negeri 1 Indralaya Utara were taught by using internet meme picture and (2) there was a significant difference in Descriptive Writing achievement between the students who were taught by using internet meme pictures and those who were not. The samples of this study were X MIPA 1 and X MIPA 2 with the total number of 64 students. To collect the data, each group was given pre-test and post-test of writing. The data were analyzed by using Paired Sample t-test and Independent Sample t-test in SPSS version 22. The results from Paired Sample $t$-test showed that there was a significant difference in Descriptive Writing achievement before and after the tenth-grade students of SMA Negeri 1 Indralaya Utara were taught by using Internet Meme Picture. The result from Independent Sample t-test of the post-test in both experimental and control groups showed that there was a significant difference in Descriptive Writing achievement between the students who were taught by using Internet Meme Picture and those who were not as the $\rho$-value both of Paired Sample t-test and Independent Sample t-test results were lower than $0.05(0.000<.05)$.
\end{abstract}

Keywords: teaching writing; writing achievement; meme picture; internet meme media

\begin{abstract}
ABSTRAK
Tujuan penelitian ini adalah untuk mengetahui apakah: (1) ada perbedaan yang signifikan dalam menulis deskriptif setelah siswa kelas sepuluh SMA Negeri 1 Indralaya Utara diajarkan dengan menggunakan Internet Meme Picture dan (2) ada perbedaan yang signifikan dalam penulisan deskriptif antara siswa yang diajar dengan menggunakan Internet Meme Picture dengan mereka yang tidak. Sampel penelitian ini adalah kelas X MIPA 1 dan X MIPA 2 dengan jumlah total 64 siswa. Untuk mengumpulkan data, setiap kelompok diberikan pre-test dan post-test penulisan. Data dianalisis dengan menggunakan Paired Sample t-test dan Independent Sample t-test dengan SPSS versi 22. Hasil dari Paired Sample t-test menunjukkan bahwa ada perbedaan yang signifikan dalam penulisan deskriptif sebelum dan sesudah siswa kelas X SMA Negeri 1 Indralaya Utara diajarkan dengan menggunakan Internet Meme Picture. Hasil Independent Sample t-test dari post-test di kedua kelompok yaitu eksperimen dan kontrol menunjukkan bahwa ada perbedaan yang signifikan dalam prestasi penulisan deskriptif antara siswa yang diajar dengan menggunakan Internet Meme Picture dan dengan mereka yang tidak. Nilai kedua t-test yaitu hasil Paired Sample t-test dan hasil Independent t-test lebih rendah dari $0,05(0,000<0,05)$.
\end{abstract}

Kata kunci: mengajar menulis; prestasi menulis; gambar meme; media meme internet

How to Cite: Inderawati, R., Ariani, D. N., Hambali, M. (2018). Enhancing Descriptive Writing Achievement of Tenth Graders by Using Internet Meme Picture. IJEE (Indonesian Journal of English Education), 5(2), 176-190. doi:10.15408/ijee.v5i2.7666.

IJEE (Indonesian Journal of English Education), 5 (2), 2018, 176-190

P-ISSN: 2356-1777, E-ISSN: 2443-0390 | DOI: http://dx.doi.org/10.15408/ijee.v5i2.7666

This is an open access article under CC-BY-SA license (https://creativecommons.org/licenses/by-sa/4.0/) 


\section{INTRODUCTION}

The government of Indonesia acknowledges English as a compulsory subject in the daily life of education for the students of many levels. Based on Indonesian Government Regulation, No. 32, 2013, English is one of the compulsory subjects which is taught from the first year of the junior high school to the university level. As the compulsory subject, students should know several kinds of English skills, such as Listening, Speaking, Reading and Writing. Writing is one of the important skills which should be learned and mastered by students. According to Harmer (2001), writing is a form of communication to deliver or to express feeling through written form. Nation (2009) also states that writing is an activity which can usefully be prepared for work in other skills of listening, speaking and reading. Moreover, Byrne (1993) insists that writing as a process to get the product is influenced by some elements such as vocabulary, grammar, organization, spelling, and pronunciation. Writing is the combination of letters which are arranged to form sentences or paragraph. Robinnet (1983) also mentions two kinds of writing which are controlled or guided writing and free writing. Controlled writing refers to activities in which are presented with a set of sentences or written text and given directions regarding ways in which these should be modified. Meanwhile, free writing is writing with no restrictions which does not have to conform to the rules of spelling, grammar, and punctuation.

In other cases, Hadley mentions that English academic writing actually seems to the learners as the most difficult skill to be mastered which implies the ability either to tell or to retell some information in the form of the text with the correct grammar and sense with good unity and coherence. Richards and Renandya (2002) say that the most difficult skill to master for the second language learners is writing because the difficulty is not only in generating and organizing ideas but also in translating these ideas into readable text. Due to the condition, Ploeger (2000) argues that writing is the activity when people can discover what they know and feel to communicate that knowledge to the audience.

The writers have ever come to some schools, SMA Negeri 1 Indralaya Utara, SMA Negeri 2 Prabumulih and SMA Negeri 1 Prabumulih to give the questionnaire for every student of tenth grade to ask the difficulty in studying English. The questionnaire consisted of 10 questions. Then, the writers took five representatives from every class to be interviewed. The writers found that the difficult skills for them are speaking and writing based on the result of the interview. Based on the questionnaire given, most of the students of SMA Negeri 1 Indralaya Utara answered writing skill as their problem in studying English. Accordingly, the 
writers decided to conduct the study in that school and continued to have an interview with one of the teachers in SMA Negeri 1 Indralaya Utara. The teacher mentioned several problems faced by the students during the English lesson. Most of the students were lack of vocabulary and did not know well how to construct good sentences. It means writing skill is the most difficult problem faced by the students. Oshima and Hogue (1999) state that academic writing is not easy as it will take study and practice for developing this skill. Therefore, the students should improve more the capability in writing and also use the appropriate strategy to improve it.

Based on curriculum 2013, there is a major competence of writing skill for tenth-grade students which expects students to be able to express the meaning of functional written text and a short essay in the form of descriptive, narrative, expository, and argumentative text in the daily life context. Furthermore, there is one basic competence that is related to this research; constructing a descriptive text spoken and written about a person, a place, a popular historic building by paying attention of social function, text structure, and language elements accurately, appropriately and contextually. Therefore, the main focus for the first semester of the tenth grade is writing descriptive text.

However, the fact shows that tenth-grade students' Descriptive
Writing achievements are still beyond the expectation. For example, the research conducted by Istiawan (2012) in the tenth graders of SMA Muhammadyah Kutoarjo found that the mean result of pre-test and post-test was not too significant from 68.5 to 71.62. Similarly, based on the data from the school, it was found that the students of tenth grade in SMA Negeri 1 Indralaya Utara have problems in writing. The passing grade (KKM) is 75 but most students have low-average score during doing the exercise of writing, based on the score given by the teacher, most of the students got a score between 60-75 when they did writing a paragraph or conversation text. Their scores were not good enough because their sentence building was not good even there were still many errors in grammar and sometimes out of the topic. Moreover, the students were also lacking the interest to write and they intended to copy some passages from the internet to fulfill their assignments. Another example, Muhsin (2017) investigated how TAD Strategy helped students write recount text through a classroom action research. Therefore, the writers need any other creative strategies to make teaching writing more effective and interesting.

Due to solving those problems, the writers were interested in using appropriate media which focused on a kind of text; descriptive text. According to Hyland (2004), descriptive text is a text which social purpose to give an 
imagined account or factual events account. Hyland (2014) mentions the generic structure of the descriptive text, they are identification and description. The primary purpose of the descriptive text is to describe a person, place, or thing in such a way that the picture is formed in the readers' mind (Hammound, 2010). In reaching the achievement of writing, there should be a media or technique used to improve writing achievement. Internet Meme Picture is a kind of picture which is popular nowadays since 2010 especially in social media like Instagram and Facebook. The meme becomes viral in this internet era. Inderawati (2011) states, "internet has become a part of daily lives that addresses for abundant websites. The internet helps people search for everything entailed. It can also be a powerful teaching tool, provide access to information and allow links to other learners" (p. 4). Meme nowadays can be a way to express something. Actually, a meme can be formed as picture, video or story which contain a joke. The term is first coined by Dawkins (1976) as an example or replicator information copied in an evolutionary process, Meme picture is an appropriate media which is useful to help students in writing the paragraph. Internet meme is commonly applied to describe the propagation of content items such as jokes, rumors, videos, or websites from one person to others via the internet (Shifman, 2013). Therefore, each message of the picture can be characteristic or idea to write a descriptive paragraph. Heylighen and Chielens, (2008) state, "to be communicated to other individuals, a meme must emerge from its storage as memory pattern or memo type and enter its media type phase, i.e. assume a physical shape that can be perceived by others. This process may be called 'expression'" (p.10).

In teaching and learning process, using appropriate teaching aid to encourage students' want to study English is important. In addition to this, a picture is one of good teaching aid. Pictures give more information and more understandable and attractive than words (Travers in Chairena, 2007). Besides, the picture does not only colorful but also can give several benefits to the students while learning process. Wright (1989) insists, "Pictures can motivate students to take part in teaching and learning process" (p.17). It is also supported by Knobel and Lankshear (2006) that a concept of meme becomes something creative, like a meme online. Moreover, Kariko (2012) indicates that memes provide a powerful new way to combine a few things such as creativity, art, message, and humor in the internet culture. Therefore, internet meme picture similar to other academic ornaments of writing such as peer assessment via Facebook group which is very beneficial to enhance writing achievement (Inderawati, Pratama, \& Loeneto, 2018) is also relevant to the application of 
curriculum 2013 which focuses on the implementation of the computer, internet, and technology.

In line with the explanation above, the study entitled as "Enhancing Tenth Grade Students' Achievement in Writing Descriptive Text by Using Internet Meme Picture Media in SMA Negeri 1 Indralaya Utara." was conducted. In this research, the writers used an experimental method that conducted by using quasi-experimental pre-test and post-test control group design to find out whether or not Meme picture was effective to enhance students' writing descriptive text achievement. This study was aimed to answer this following research questions: (1) was there any significant difference in Descriptive Writing achievement of the tenth grade students of SMA Negeri 1 Indralaya Utara before and after they were taught by using Internet Meme Picture?, (2) was there any significant difference in Descriptive Writing achievement of the tenth grade students of SMA Negeri 1 Indralaya Utara between the students who were taught by using Internet Meme Picture and those who were not?

\section{METHOD}

A quasi-experimental research method and pre-test post-test control group design were applied in this research to know whether or not there was a significant difference in Descriptive Writing achievement before and after they were taught by using internet meme picture media and whether or not there was a significant difference in Descriptive Writing achievement between the students' who were taught by using internet meme picture and those who were not. In applying the media, treatment was done for 16 meetings and there were also two meetings of pre-test and post-test.

The samples of this study were from tenth-grade students of natural science class of SMA Negeri 1 Indralaya Utara with the total number of 64 who were divided into two groups, namely, experimental group and control group. Each group had 32 students who were chosen by the English teacher (purposive sampling technique). The English teacher decided $X$ MIPA 1 as the experimental group and X MIPA 2 should belong to the control group based on their last examination score.

To collect the data, both the experimental group and control group were assigned a writing test. Brown (2001) says, "Test is a method to measure a person's knowledge or ability..." (p. 384); the students were assigned the test twice as pretest and posttest. A pretest was administered before the writer applied the treatment of her study to experimental group students. Meanwhile, a posttest was administered after the end of writing experimental teaching. The form of the test applied was similar, Descriptive Writing test. 
The validity is one of the characteristics of the good study. A test should be valid to know whether there is an improvement or not. The validity is necessary because it has a function to measure whether the test was acceptable to the variables which used in the writer's research study. Tuckman (1978) mentions that the validity of a test represents the extent to which a test measures what it purports to measure. In order to know whether the test was appropriate or not, the writer checked the curriculum, syllabus, and students' textbook used by the tenth graders of SMA Negeri 1 Indralaya Utara. In this study, curriculum 2013 was used to know whether or not the content of items had a high degree of content validity. After that, the writer asked for two expert judgments and also got feedback from her thesis advisors. The test items were constructed based on the table of test specifications so that the writing test had a high degree of content-related evidence of validity.

Brown (2001) states, "Reliability is consistency and dependability of a test" (p. 386). For the reliability of the test, the inter-rater reliability was used. Creswell (2012) mentions that in making observations of behavior, a procedure will be used through some stages or steps. It involves observations made by two or more individuals of an individual's or several individuals' behavior is called Inter-rater reliability. The writer asked two raters to give scores of student's writing test based on the rubric which is provided by the writer. The results of students' writing were correlated by using Pearson Product Moment Correlation Coefficient in SPSS 22. The test is reliable if the value is at least 0.70 (Wallen and Fraenkel, 1991). Based on the calculation from statistical analyses, it was found that the results reliability of writing test coefficient were $0.729,0.875,0.741,0.732$. it means that the data were reliable.

After assuring the validity and reliability, the paired sample t-test and independent sample t-test for analyzing the data by using SPSS version 22 . Paired sample t-test was used to analyze the data obtained from pretest and posttest of the experimental group. Meanwhile, independent sample t-test was used to analyze the data obtained from the control group and the experimental group. After running the paired sample t-test and independent sample t-test analyses, the significance level (in the two-tailed test) was found.

\section{FINDINGS AND DISCUSSIONS}

\section{Score Distribution of Experimental and Control Groups}

The results of students' Descriptive Writing achievement were scored with an interval between 0-100 and distributed based on five categories: Very Good, Good, Enough, Poor, and Failed. The following table shows the results score from both groups (experimental group and control group). 
Table 1 presents the results of pretest and posttest of the experimental group.

The lowest score of pretest was 38 and the highest score was 63. As shown in table 1, Out of 32 students, 14 students got a poor category, 12 students got the average category and six students got failed category. There was no student getting a good or very good category. Therefore, $43.75 \%$ of the total students got a poor category, $18.75 \%$ students got failed category and $37.5 \%$ of them got an average category. After all experimental group students got the treatment for sixteen meetings by using internet meme picture which was prepared by the writer, they were given a posttest. The highest score of posttest was 90 and the lowest score was 54 . Thus, most of the students were in the very good and good category. There were 7 students who got a very good category, 15 students got a good category and 10 students got an average category. It means that $68.75 \%$ of the total students got the score above 66 (very good and good category) and $31.25 \%$ got the score minimum 51 (average category). None of the students got the poor or failed category. In addition, based on the differentiation of pretest and posttest of experimental group students, there was an improvement from students' score.

In the control group, the lowest score of pretest was 33 and the highest one was 63. Based on table 2, there were 5 students who got failed category, 13 students got the poor category and other 14 students got an average category. Meanwhile, there was no student who got the category of good and very good. In addition, $56.25 \%$ of the total of students got a score below 50 and only $43.75 \%$ of the total of the control group students got pretest score above 51 .

Table 1: The Score Distribution of the Experimental Group

\begin{tabular}{llllll}
\hline Score & Category & Pretest & \multicolumn{3}{c}{ Posttest } \\
\cline { 3 - 6 } Interval & & Freq & Percentage & Freq & Percentage \\
$\mathbf{8 1 - 1 0 0}$ & Very Good & 0 & $0 \%$ & 7 & $21.875 \%$ \\
$\mathbf{6 6 - 8 0}$ & Good & 0 & $0 \%$ & 15 & $46.875 \%$ \\
$\mathbf{5 1 - 6 5}$ & Average & 12 & $37.5 \%$ & 10 & $31.25 \%$ \\
$\mathbf{4 1 - 5 0}$ & Poor & 14 & $43.75 \%$ & 0 & $0 \%$ \\
$\mathbf{0 - 4 0}$ & Failed & 6 & $18.75 \%$ & 0 & $0 \%$ \\
\hline
\end{tabular}

Table 2: The Score Distribution of the Control Group

\begin{tabular}{llllll}
\hline Score & Category & Pretest & & Posttest & \\
\cline { 3 - 6 } Interval & & Freq & Percentage & Freq & Percentage \\
$\mathbf{8 1 - 1 0 0}$ & Very Good & 0 & $0 \%$ & 0 & $0 \%$ \\
$\mathbf{6 6 - 8 0}$ & Good & 0 & $0 \%$ & 0 & $0 \%$ \\
$\mathbf{5 1 - 6 5}$ & Average & 14 & $43.75 \%$ & 15 & $46.875 \%$ \\
$\mathbf{4 1 - 5 0}$ & Poor & 13 & $40.625 \%$ & 12 & $37.5 \%$ \\
$\mathbf{0 - 4 0}$ & Failed & 5 & $15.625 \%$ & 5 & $15.625 \%$ \\
\hline
\end{tabular}


Although control group students were not exposed to the treatment there was a bit different in their percentage of posttest score. As the explanation from the table above, there still 5 students $(15.625 \%)$ got the failed category. Meanwhile, $46,875 \%$ out of the 32 students from the control group or 15 students could reach the average category and 12 students got a poor category. It means that there were 27 students who got the score above 40 . The mean score of pretest from the control group was $48.34 \%$ and the posttest was $47.97 \%$ After the students' score of the control group was calculated, the writer could draw the conclusion there was a little improvement in the control group. It could happen because at the same time those students also learned from their teacher although they did not get the treatment they were able to take the knowledge from their teacher explanation. But overall, the improvement was not so significant because there was no improvement in the mean between pretest and posttest of the control group.

\section{Normality and Homogeneity of the Data}

Before doing the t-test, the normality of the data was checked by using

One-Sample

Kolmogorov-Smirnov test. Based on the result obtained, the significance values in two-tailed testing from pretest and posttest of the experimental group were .218 and .383 meanwhile from the control group the pretest and posttest reached .409 and .236. It can be concluded that the data were normally distributed since all of the significance values were higher than 0.05 .

Homogeneity test was done in order to find out whether the sample groups from the population had a similar variance. The data are homogenous if the significance value (2-tailed) is higher than 0.05. Therefore, the Levene's test was applied in order to check the homogeneity of the sample groups (experimental and control group).

Table 3: Test of Homogeneity of Variances

\begin{tabular}{lcccc}
\hline Test & $\begin{array}{l}\text { Levene } \\
\text { Statistic }\end{array}$ & df1 & df2 & Sig. \\
\hline $\begin{array}{l}\text { Posttest } \\
\text { EG-CG }\end{array}$ & 1.766 & 6 & 24 & .149 \\
$\begin{array}{l}\text { Pretest } \\
\text { EG-CG }\end{array}$ & 4.285 & 7 & 21 & .004 \\
$\begin{array}{l}\text { Pre-Post } \\
\text { EG }\end{array}$ & .976 & 7 & 22 & .473 \\
$\begin{array}{l}\text { Pre-Post } \\
\text { CG }\end{array}$ & .274 & 6 & 24 & .944 \\
\hline
\end{tabular}

From the table above, the result of the homogeneity test showed that the significance value of pretest and posttest in the experimental group was .473 , it means that the data were homogenous. The significance value of pretest and posttest in control group was .944 and the data set was homogenous too. Next, the significance value of posttest of both experimental and control groups was .149 it was higher than 0.05 , it means that the data were homogenous as well. Meanwhile, the significance value of pretest of both 
in the experimental and control groups was .004 which is lower than 0.05 , it means that the data were not homogenous.

Sometimes, inhomogeneity could happen, Azwar (2010) describes, "The assumption of homogeneity of variance can be ignored without a large risk as long as we have the same number $(\mathrm{N})$ in each sample" (p. $4)$.

\section{The Result of the Paired Sample T-test}

After the result of homogeneity was checked, t-test (paired sample t-test and independent sample t-test) could be applied to continue the data analyses.

Based on the result of the paired sample t-test in the experimental group, the mean score of the posttest was higher than the pretest. The posttest was 71.63 while the pretest 48.53 with the mean difference was that of 23.074. The standard deviations of pretest and posttest of the experimental group were 7.405 and 10.594. The standard error means were 1.309 and 1.873. Since the p-value (sig-two tailed) of the experimental group was less than 0.05 $(.000<0.05)$ and $\mathrm{t}$-obtained was higher than $\mathrm{t}$-table $(15.491>2.040)$ so the null hypothesis $\left(\mathrm{H}_{0} 1\right)$ was rejected and the research hypothesis $\left(\mathrm{H}_{1} 1\right)$ was accepted. Therefore, there was a significant difference between the pretest and posttest result of the experimental group.

Meanwhile, the result of paired sample t-test in the control group showed that the mean score of posttest was 47.97 and the mean score of pretest was lower than that of the postest (48.34) with the mean difference was .375 . The standard deviations of pretest and posttest of the control group were 7.128 and 7.137. The standard error means were 1.260 and 1.262. Since p-value (sig-two tailed) of the control group was higher than $0.05 \quad(.795>0.05)$ and t-obtained was lower than t-table $(.262<$ 2.040), it could be indicated that there was no significant difference in pretest and posttest of the control group.

Table 4: Paired Sample T-Test

\begin{tabular}{llllllllll}
\hline Group & Test & Mean & $\begin{array}{l}\text { Mean } \\
\text { Diff }\end{array}$ & $\begin{array}{l}\text { Std. } \\
\text { Dev }\end{array}$ & $\begin{array}{l}\text { Std. } \\
\text { Mean }\end{array}$ & Error & T & Df & $\begin{array}{l}\text { Sig. } \\
\text { (2-tailed) }\end{array}$ \\
\hline Exp Group & Pretest & 48.53 & 23.094 & 7.405 & 1.309 & 15.491 & 31 & .000 \\
& Posttest & 71.63 & & 10.594 & 1.873 & & & \\
Cont & Pretest & 48.34 & .375 & 7.128 & 1.260 & .262 & 31 & .795 \\
Group & Posttest & 47.97 & & 7.137 & 1.262 & & & \\
\hline
\end{tabular}


The Result of Independent Sample t-test

In order to answer the second research question, the writer compared the result of the posttest in the experimental group and control group by using independent sample t-test. The result shows in the following table:

Table 5: Independent Sample T-Test

\begin{tabular}{llllllll}
\hline Group & $\begin{array}{l}\text { Me } \\
\text { an }\end{array}$ & $\mathbf{N}$ & $\begin{array}{l}\text { Std. } \\
\text { Devia } \\
\text { tion }\end{array}$ & $\begin{array}{l}\text { St } \\
\text { d. } \\
\text { Err } \\
\text { or } \\
\text { me } \\
\text { an }\end{array}$ & & & \\
& & & & $\begin{array}{l}\text { d } \\
\text { f }\end{array}$ & $\begin{array}{l}\text { Sig. } \\
\text { (2-tai } \\
\text { led) }\end{array}$ \\
& & & & & & \\
\hline Experi & 71. & 3 & 10.594 & 1.8 & 10. & 6 & .000 \\
mental & 63 & 2 & & 73 & 476 & 2 & \\
Control & 47. & 3 & 7.137 & 1.2 & 10. & 6 & .000 \\
& 97 & 2 & & 62 & 476 & 2 & \\
\hline
\end{tabular}

Based on the table, the mean score of posttest of the experimental group was higher than that of the control group $(71.63>47.97)$. Since the t-obtained (10.476) was higher than the t-table (1.999) and the $\rho$-value (sig-two tailed) was less than $0.05(.000<0.05)$ the null hypothesis $\left(\mathrm{H}_{0} 2\right)$ was rejected and the research hypothesis $\left(\mathrm{H}_{1} 2\right)$ was accepted. It means that there was a significant difference in posttest between the students who were taught (experimental group) by using internet meme picture and those who were not (control group).

There are some points to be discussed based on the findings above. First, the writer obtained the results of the pretest and posttest in the experimental group to find out whether or not there was any significant difference before and after the tenth grade students of SMA Negeri 1 Indralaya Utara were taught by using internet meme picture. The mean score of pretest and posttest of the experimental group had increased after the students were exposed to the treatmett (internet meme picture) from 48.53 (pretest) to 71.63 (posttest). The experimental group got 16 meetings of the treatment. By doing the treatment, the experimental group students' achievement in Descriptive Writing had increased. It could be seen from the process of learning and teaching. The students had understood how to write descriptive text well in the third day of the treatment until the last treatment. Their score of the pretest to posttest had improved. In the pretest, the students' score was in the category of failed, poor and average only. Whereas, the posttest result of their score was in the average, good and very good category. It means that there was an improvement. The improvement itself was significant. In other words, the experimental group performance was better in posttest after they were treated by using Internet Meme Picture. Based on the results obtained, there was an improvement only in the experimental group while the control group was not. However, the control group had not an improvement in their score. It could be seen from the pretest and posttest score (48.4 to 47.97). There was a little improvement in some students' scores of the control group but the mean score of the posttest was lower than that of 
the pretest. In other words, the progress of the control group was not as significant as the experimental group.

Based on the findings above, it could be assumed that the improvement also happened because of the influence from the way the writer taught by using the media applied. Internet meme picture was an appropriate media. It is relevant to the statement of Wright (1989) that using pictures in teaching and learning process can make students to be motivated and take a part; therefore, the internet meme picture is able to motivate students' want to learn English writing. Furthermore, Travers (in Chairena, 2007) states that pictures are more understandable and attractive than words and gives retentive information too. Internet meme picture is a kind of picture which was used to help students in generating the ideas and easing the students to find the word adjective from the picture showed.

Second, during the process of learning, the writer found out some students did not know exactly how to write in English well. Especially in writing descriptive text. The students were lack of grammar, vocabulary, and the generic structure of the descriptive text. According to Hyland (2014) the generic structure of descriptive text which are: identification and description. Based on the result of this study, the writer found out that some of the students were confused to start the paragraph. They were confused for both, to describe the characters of the topic and to write the sentence grammatically. Those students were lack of adjectives vocabulary. They couldn't find an appropriate sentence to describe their topic in the part of the description. Thus, in the pretest result, most of the students did not focus on one topic. For example, one student chose the topic to describe her mother then she actually should describe her mother only about the characteristics and appearances while that student just described her mother in the past. Moreover, in the first and second day of treatment, some students still did not focus on one topic although the media had applied. They did not pay attention fully to the pictures. As a result, what they wrote were out of the picture topic.

As the explanation before although in the first and second meeting they still did not understand but on the third day of the treatment they began to understand how to write correctly. The writer always guided the students with some stages. First, the writer gave brainstorming; the writer asked the students to tell some examples of adjectives. They had to categorize some adjectives and made the opposites too. After the students were familiar with the kind of adjectives, the next stage was imagining and generating. Before the process of imagining was done, the writer explained the purpose and the generic structure of descriptive text first. In teaching writing, it's very important to explain the purpose, generic structure, and language feature in order to ease 
them and to make them more focus on the topic (Fajri, Inderawati, \& Mirizon, 2015). Then, the writer guided the students to take part in imagining step, those students were guided to observe the picture given in that day. Firstly, they were asked to observe the picture based on the appearance side for example: How did it look like? How was it? Was it beautiful? Was it tall or thin? Secondly, the writer guided the students to find the adjectives of the object based on the characteristic side. It could be gotten from the caption of the picture. As usual, each meme picture contains a message which gives a joke or humor sense but in a unique way, it can be a happening tragedy or bullying someone/something. To be communicated to other individuals, a meme must emerge from its storage as memory pattern or memotype and enter its mediotype phase, i.e. assume a physical shape that can be perceived by others. This process may be called 'expression' (Heylighen \& Chielens, 2008); therefore, a caption in a meme picture could describe what a subject was. For example, there was a meme picture of a man with a smile and his thumb. The caption was "first day work, very excite". Then, after the students were asked to observe the adjective by his appearance, the writer asked them to guess what that man's characteristics were by that caption; the students could find if that man was a diligent man, loyal and high-spirit person.
After getting the adjectives from several sides, then all students could generate their Descriptive Writing well because they did not only do writing but also 'play' with their imagines. It is in line with Knobel and Lankshear (2006) that a concept of meme becomes something creative for example a meme online. Memes combine some points like art, creativity, message and humor in one frame in the internet culture (Kariko, 2012). So that, because of the experimental group students everyday in that time always given the treatment, at last, they understood how to write well. In each meeting, the students were asked to write a descriptive text with variance topic or picture, therefore they would be more innovative and creative in enhancing their ideas.

\section{CONCLUSION AND SUGGESTION}

Based on the previous explanation, the writers concluded that teaching the tenth grade students of SMA Negeri 1 Indralaya Utara by using Internet Meme Picture was effective to improve Descriptive Writing achievement. The data showed that the score of the students in the experimental group was significantly improved after treatment. It can bee is seen from the results of statistical analysis. Therefore, they know how to write correctly in grammar and meaning and teaching students by using Internet Meme Picture Media is a good choice to 
improve students' Descriptive Writing achievement.

There are some suggestions to be offered by the writers to the teachers, students, and other further researchers. First of all, due to the weaknesses of the students during the teaching and learning process, the writers would like to give some suggestions to the teacher. It's a must actually for the teacher to find an appropriate and effective strategy or media to make students like writing and to improve students' writing. Besides, the teacher also should focus on students' sentence building. Most of the students did not even know what the grammaticals are. They also often make an error in identifying kinds of part of speech. Thus, the teachers should also give motivation to the students. Obviously, most of the students are creative, so it's a challenge for the teacher to enhance students' creativity. It's really important to make students get impressed to what they learn.

Secondly, to the students. The writers suggest that should keep their confidence in learning English and the students should not be afraid in doing writing or learning English especially in doing writing. Because, without confidence, the effort is not worth. Besides, the students should also keep doing practice. They should keep on upgrading their vocabulary knowledge and the rule of sentence building. The first step is 'understanding the word', after that everything will be easier. Practice makes perfect. that's a fact.

The last part is the suggestion for further researchers in the next day. The writers hope that this study can be a consideration to fulfill students' achievement in learning English. The writers also suggest that the next researchers should optimalize their mind to look for another good and appropriate strategy or media to improve students' writing achievement. In other words, the writers really suggest to the next researchers to apply this media to other English skills (speaking, reading or listening) or the next researchers can also try this way to the same skill but for the different text, such as narrative text, recount text or other text.

\section{REFERENCES}

Azwar, S. (2010). Asumsi-asumsi dalam inferensi statistika. Retrieved from Gadjah Mada University website:http://azwar.staff.ugm.ac .id/files/2010/04/Asumsi-asumsi -dalam-Inferensi-Statistika1.pdf/.

Brown, H. D. (2001). Teaching by the principle: An interactive approach to language pedagogy (2nd ed.). White Plains, NY: Pearson Education.

Byrne, D. (1993). Teaching Writing Skills (Longman Handbooks for Language Teachers). London, UK: Longman Group UK Limited. 
Chairena, M.S. (2007). The Use of pictures to teach Writing Descriptive Text of the eight year students at SMP Negeri 13 Semarang (unpublished undergraduate thesis). Semarang State University: Semarang. Retrieved from http//lib.unnes.ac.id.

Creswell, J. W. (2012). Educational research: Planning, conducting, and evaluating quantitative and qualitative research ( $4^{\text {th }}$ ed.). Boston, MA: Pearson.

Dawkins, R. (1976). The selfish gene. 30th anniversary ed xxiii,360. Oxford, UK: Oxford University Press.

Depdiknas. (2013). Sistem Pendidikan Nasional Peraturan Pemerintah No. 32. Jakarta, Indonesia: Depdiknas RI. Retrieved from http://www.dpr.go.id/.

Fajri, H. M., Inderawati, R., \& Mirizon, S. (2015). The implementation of peer editing technique to improve students' writing achievement. Journal of English Literacy Education, 2 (2), 48-57. Retrieved from http://ejournal.unsri.ac.id/index. php/jenglish/article/view/2307.

Hadley, A.O. (1993). Teaching language in context. Boston, MA: Heinle \& Heinle.

Hammound, Y. M. (2010). Creative Writing. Riyadh: Zahrat Al-Sahra'a International School.
Harmer, J. (2001) The practice of English Language Teaching (4th ed.). Cambridge, UK: Pearson Longman.

Heylighen, F., \& Chielens, K. (2008). Evolution of culture and memetics. In R. A. Meyers (Ed.), Encyclopedia of Complexity and Systems Science (pp. 3205-3220). Germany: Springer.

Hyland, K. (2004). Genre and Second Language Writing. Michigan: The University of Michigan Press.

Inderawati, R. (2011). From classroom to peer comment on Facebook: Bridging to establish learners' literacy, 6 . Retrieved from http://www.conference.pixel-onli ne.net.

Inderawati, R., Pratama, M. H., \& Loeneto, B.A. (2018). Peer assessment in Facebook comment column about one topic in Writing II Subject of the Fourth Semester Students of Sriwijaya University English Study Program. English Franca: Academic Journal of English Language and Education, 2(1), 49-72.

Istiawan, R. (2012). The effectiveness of using Clustering Technique to teach Writing Descriptive Text to the tenth grade students of SMA Muhammadyah Kutoarjo in Academic Year 2012/2013. Retrieved from http://www.ejournal.umpwr.ac.i d. 
Kariko, A. Z. T. (2012). Humorous writing exercise using Internet Memes on English classes. Jurnal Lingua Cultura, 5, 188-199.

Knobel, M., \& Lankshear, C. (2006). New literacies: Everyday practices and classroom learning., Berkshire, UK: Open University Press.

Muhsin, M. A. (2017). Improving students' Writing Skills of Recount Text by applying Translation-Action-Detail (TAD) Strategy. IJEE (Indonesian Journal of English Education), 4(2), 156-167. doi: 10.15408/ijee.v4i2.2430.

Nation, I. S. P. (2009) Teaching ESL/EFL reading and writing. Newyork, NY: Routledge.

Oshima, A., \& Hogue, A. (1999). Writing Academic English (3rd ed.). London, UK: Longman .

Ploeger, K. M. (2000). Simplified paragraph skills. Lincolnwood: NTC/Contemporary Publishing Group.

Richard, J. C., \& Renandya, W.A. (2002). Methodology in language teaching: An anthology of current practice.
Cambridge, UK: Cambridge University Press.

Robinnet, B. W. (1983). Teaching English to Speaker of Other Language: Substances and technique. New York: McGraw-Hill International Book Company.

Shifman, L. (2013). Memes in a digital world: Reconciling with a conceptual troublemaker, $4 . \quad$ doi: 10.1111/jcc4.12013.

Tuckman, B. W. (1978). Conducting educational research (2nd ed.). San Diego, CA: Harcourt Brace Javanovich, Publishers.

Wallen, N. E., \& Fraenkel, J.R. (1991). Educational research: A guide to the process. New York: McGraw Hill.

Wright, A. (1989). Visual materials for the language teacher. London: Longman. 